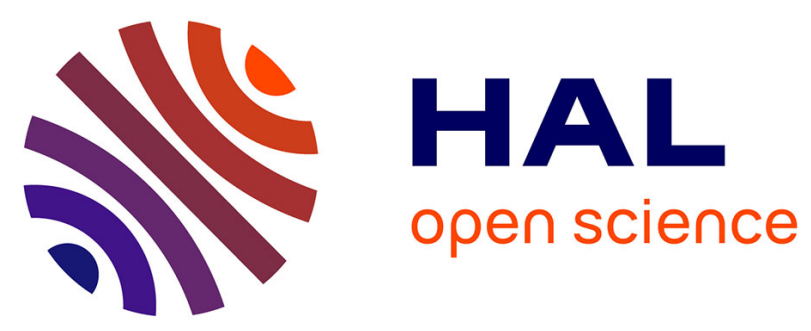

\title{
Formation and Structure of a Sterically Protected Molybdenum Hydride Complex with a 15-Electron Configuration: $[(1,2,4-\mathrm{C} 5 \mathrm{H} 2 \mathrm{tBu} 3) \mathrm{Mo}(\mathrm{PMe} 3) 2 \mathrm{H}]+$
} Miguel Baya, Jennifer Houghton, Jean-Claude Daran, Rinaldo Poli

\section{- To cite this version:}

Miguel Baya, Jennifer Houghton, Jean-Claude Daran, Rinaldo Poli. Formation and Structure of a Sterically Protected Molybdenum Hydride Complex with a 15-Electron Configuration: [(1,2,4C5H2tBu3) $\mathrm{Mo}(\mathrm{PMe} 3) 2 \mathrm{H}]+$. Angewandte Chemie International Edition, 2007, 46 (3), pp.429-432. 10.1002/anie.200603628 . hal-03194689

\section{HAL Id: hal-03194689 \\ https://hal.science/hal-03194689}

Submitted on 9 Apr 2021

HAL is a multi-disciplinary open access archive for the deposit and dissemination of scientific research documents, whether they are published or not. The documents may come from teaching and research institutions in France or abroad, or from public or private research centers.
L'archive ouverte pluridisciplinaire HAL, est destinée au dépôt et à la diffusion de documents scientifiques de niveau recherche, publiés ou non, émanant des établissements d'enseignement et de recherche français ou étrangers, des laboratoires publics ou privés. 


\section{Formation and structure of a sterically protected molybdenum hydride complex with a 15-electron configuration: $\left[\left(1,2,4-\mathrm{C}_{5} \mathrm{H}_{2} t \mathrm{Bu}_{3}\right) \mathrm{Mo}\left(\mathrm{PMe}_{3}\right)_{2} \mathrm{H}\right]^{+* *}$}

\author{
Miguel Baya, Jennifer Houghton, Jean-Claude Daran, \\ Rinaldo Poli*
}

Hydride complexes generally feature a closed shell configuration They are implicated in a variety of catalytic cycles and are also intermediates of $\mathrm{C}-\mathrm{H}$ oxidative addition processes. Open-shell, paramagnetic versions have not so far demonstrated broad utility, mainly because of their instability and multitude of decomposition pathways, including deprotonation, ${ }^{[1]}$ disproportionation, ${ }^{[2]}$ dihydrogen reductive elimination (for complexes containing at least two hydride ligands), ${ }^{[3]}$ atom transfer, etc. ${ }^{[4]}$ Yet, open-shell hydride complexes appear to play a role in enzymatic processes such as hydrogenase and nitrogenase, ${ }^{[5-8]}$ and their implication in a variety of electrocatalyzed transformation may be envisaged. Therefore, they are attracting renewed interest.

One-electron oxidation of compounds containing two 1-electron ligands, $[\mathrm{M}](\mathrm{X})(\mathrm{Y})$, may result in the reductive elimination of $\mathrm{X}-\mathrm{Y}$ (oxidatively induced reductive elimination, OIRE). This has most clearly been demonstrated for dialkyl complexes, $[\mathrm{M}](\mathrm{R})_{2}$, to give the organic product $\mathrm{R}-\mathrm{R}$ plus products originating from $[\mathrm{M}]^{+} \cdot{ }^{[9-12]}$ When $\mathrm{X}=\mathrm{Y}=\mathrm{H}$, the process may lead to $\mathrm{H}_{2}$ evolution, since the oxidation of a polyhydride complex $[\mathrm{M}] \mathrm{H}_{\mathrm{n}}$ ix expected to favour the rearrangement to a nonclassical isomer, $[\mathrm{M}] \mathrm{H}_{\mathrm{n}-2}\left(\mathrm{H}_{2}\right)^{+} \cdot{ }^{[4,13,14]} \mathrm{In}$ fact, the oxidation of polyhydride complexes often results in dihydrogen evolution, ${ }^{[15]}$ but the instability and the multitude of decomposition pathways of the intermediate oxidized polyhydride complexes often obscures the clean identification of OIRE. ${ }^{[4]}$ Indeed, the oxidation of complexes $\mathrm{Cp} * \mathrm{Ru}\left(\mathrm{PPh}_{3}\right) \mathrm{H}_{3}{ }^{[13]}$ and $\mathrm{Os}\left(\mathrm{Pi}_{3} \mathrm{Pr}_{3}\right)_{2} \mathrm{H}_{6}{ }^{[16]}$ leads to hydrogen evolution, but this was shown to take place following proton transfer from the unstable oxidized complex to residual starting material, rather than from direct reductive elimination.

We have recently reported the first unambiguous case of $\mathrm{H}_{2}$ OIRE for complex $\mathrm{Cp} * \mathrm{Mo}($ dppe $) \mathrm{H}_{3}\left(\mathrm{dppe}=\mathrm{Ph}_{2} \mathrm{PCH}_{2} \mathrm{CH}_{2} \mathrm{PPh}_{2}\right)$, thanks to the characterization of the solvent-stabilized product, $[\mathrm{Cp} * \mathrm{Mo}(\mathrm{dppe})(\mathrm{S}) \mathrm{H}]^{+}$, by $\mathrm{EPR}\left(\mathrm{S}=\mathrm{THF}, \mathrm{CH}_{2} \mathrm{Cl}_{2}\right)^{[3]}$ and electrochemistry $(\mathrm{S}=\mathrm{MeCN}),{ }^{[17]}$ although the structure of the product could not be confirmed crystallographically. The oxidized trihydride complex, $\left[\mathrm{Cp} * \mathrm{Mo}(\mathrm{dppe}) \mathrm{H}_{3}\right]^{+}$, also decomposes simultaneously by deprotonation and disproportionation. All three pathways

[*] Dr. M. Baya, Dr. J. Houghton, Dr. J.-C. Daran, Prof. R. Pol Laboratoire de Chimie de Coordination, UPR CNRS 8241 liée par convention à l'Université Paul Sabatier et à l'Institut National Polytechnique de Toulouse, 205 Route de Narbonne, 31077 Toulouse, France.

Fax: (+) 33-561553003

E-mail: poli@lcc-toulouse.fr

[**] We thank the European Commission through the HYDROCHEM program (contract HPRN-CT-2002-00176) for support of this work. MB thanks the Spanish Ministerio de Educación y Ciencia for a post-doctoral fellowship. occur via the nonclassical intermediate $\left[\mathrm{Cp} * \mathrm{Mo}(\mathrm{dppe}) \mathrm{H}\left(\mathrm{H}_{2}\right)\right]^{+}$, although theoretical calculations and circumstantial evidence indicates that the oxidized complex adopts a classical structure. ${ }^{[17]}$ We have argued that both stronger electron donation and greater steric protection by the ligands stabilize paramagnetic hydride complexes by disfavouring, via different mechanisms, the various decomposition pathways. ${ }^{[4]}$ We have therefore turned our attention to a new Mo system, using the more donating $\mathrm{PMe}_{3}$ ligand in place of dppe and the more sterically protecting $1,2,4-\mathrm{C}_{5} \mathrm{H}_{2} t \mathrm{Bu}_{3}$ in place of $\mathrm{Cp}^{*}$. This has allowed us to isolate and structurally characterize, for the first time, the starting and end products of the $\mathrm{H}_{2}$ OIRE, $\left[\mathrm{Cp}^{t \mathrm{Bu}} \mathrm{Mo}\left(\mathrm{PMe}_{3}\right)_{2} \mathrm{H}_{3}\right]^{+}$and $\left[\mathrm{Cp}^{t \mathrm{Bu}} \mathrm{Mo}\left(\mathrm{PMe}_{3}\right)_{2} \mathrm{H}\right]^{+} \quad\left(\mathrm{Cp}^{t \mathrm{Bu}}=1,2,4-\right.$ $\left.\mathrm{C}_{5} \mathrm{H}_{2} t \mathrm{Bu}_{3}\right)$.

The starting compound, $\mathrm{Cp}^{t \mathrm{Bu}} \mathrm{Mo}\left(\mathrm{PMe}_{3}\right)_{2} \mathrm{H}_{3}$, was prepared by adapting the procedure previously employed for $\mathrm{Cp} * \mathrm{Mo}-$ (dppe) $\mathrm{H}_{3},{ }^{[18]}$ from $\mathrm{Cp}^{t \mathrm{Bu}} \mathrm{MoCl}_{4}$ and $\mathrm{LiAlH}_{4}$ in the presence of $\mathrm{PMe}_{3}$. Its X-ray structure shows a very similar geometry to that of $\mathrm{Cp} * \mathrm{Mo}(\mathrm{dppe}) \mathrm{H}_{3},{ }^{[19]}$ with the two $\mathrm{PMe}_{3}$ ligands symmetrically disposed in adjacent coordination positions (P-Mo-P angle of 93.71(2) ${ }^{\circ}$ and far away from the $\mathrm{Cp}^{t \mathrm{Bu}}$ ligand, see Figure 1(a). ${ }^{[20]}$ When considering the $\mathrm{Cp}^{\mathrm{tBu}}$ ring as occupying a single coordination position at the ring centroid, it can best be described as a distorted trigonal prism.

<insert Figure 1 here>

Figure 1. ORTEP views of (a) $\mathrm{Cp}^{\mathrm{ABu}} \mathrm{Mo}\left(\mathrm{PMe}_{3}\right)_{2} \mathrm{H}_{3}$ and (b) the cation in $\left[\mathrm{Cp}^{\mathrm{AB} u} \mathrm{Mo}\left(\mathrm{PMe}_{3}\right)_{2} \mathrm{H}_{3}\right] \mathrm{PF}_{6}$. Ellipsoids are drawn at the $30 \%$ probability level. All hydrogen atoms except the hydrides are not shown for clarity. Relevant parameters are listed in the order $a / b$ (the parameters for the cation are averaged over two independent molecules in the asymmetric unit). Distances ( $\AA$ ): Mo-CNT, 2.0150(2)/2.002(2); $\quad$ Mo-P1, 2.3832(6)/2.473(2); $\quad$ Mo-P2, 2.3801(6)/2.473(2); Mo-H1, 1.58(3)/1.62(4); Mo-H2, 1.57(3)/1.54(4);

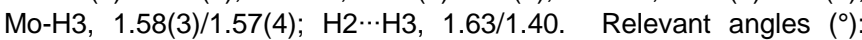
CNT-Mo-P1， 130.62(2)/127.0(8); CNT-Mo-P2, 132.14(2)/127.4(3); P1-Mo-P2, 93.71(2)/100.3(1); CNT-Mo-H1, 106(1)/104(2); CNT-Mo$\mathrm{H} 2,107(1) / 108(2)$; CNT-Mo-H3, 114(1)/108(2). CNT is the $\mathrm{Cp}^{\mathrm{tBu}}$ ring centroid.

A preliminary electrochemical investigations shows a reversible one-electron oxidation process at $\mathrm{E}_{1 / 2}=-0.89 \mathrm{~V}$ in THF and $-0.93 \mathrm{~V}$ in $\mathrm{MeCN}$ vs. ferrocene, suggesting that the oxidation product has a certain stability. The stoichiometric oxidation was accomplished by the use of $\mathrm{Cp}_{2} \mathrm{Fe}^{+} \mathrm{PF}_{6}$ in THF, affording a product that was sufficiently stable to be isolated and crystallized. ${ }^{[20]}$ Its structure is closely related to that of the neutral precursor, see Figure 1(b). The $\mathrm{Mo}-\mathrm{Cp}^{t \mathrm{Bu}}$ (centroid) separation shortens upon oxidation, whereas the Mo-P bonds lengthen. Not much significance should be attributed to the parameters involving the imprecisely determined hydride positions, but the most notable change is an apparent decrease of the $\mathrm{H} 2 \cdots \mathrm{H} 3$ contact $(1.40 \AA$ in the cation vs. $1.63 \AA$ in the neutral complex), suggesting an increased $\mathrm{H}-\mathrm{H}$ attraction in the oxidized complex. The complex, however, can still be described as a classical trihydride. In THF solution, the complex exhibits a rather broad EPR spectrum at ambient temperature, but sharpening occurs at lower temperatures allowing the identification of the expected quartet of triplet feature, due to coupling to three equivalent hydride ligands and to the $\mathrm{P}$ nuclei of two equivalent phosphine ligands, flanked by the ${ }^{95} \mathrm{Mo}$ and ${ }^{97} \mathrm{Mo}$ isotope satellites. Satisfactory simulation, see Figure 2, provides the hyperfine coupling constants $\mathrm{aP}=36.2 \mathrm{G}$, aH $=11.4 \mathrm{G}$ and $\mathrm{amo}=30.8 \mathrm{G}$, which compare with 
those of the analogous but less thermally stable $\left[\mathrm{Cp} * \mathrm{Mo}(\mathrm{dppe}) \mathrm{H}_{3}\right]^{+}$ complex $\left(\mathrm{aP}=29.8 \mathrm{G}\right.$; $\left.\mathrm{aH}_{\mathrm{H}}=11.8 \mathrm{G}\right)$.

\section{<insert Figure 2 here>}

Figure 2. EPR spectrum of compound $\left[\mathrm{Cp}^{\mathrm{tBu}} \mathrm{Mo}\left(\mathrm{PMe}_{3}\right)_{2} \mathrm{H}_{3}\right] \mathrm{PF}_{6}$ in $\mathrm{THF}$ solution $(T=193 \mathrm{~K})$.

Although compound $\left[\mathrm{Cp}^{t \mathrm{Bu}} \mathrm{Mo}\left(\mathrm{PMe}_{3}\right)_{2} \mathrm{H}_{3}\right] \mathrm{PF}_{6}$ is quite stable as a crystallized solid and in THF solution at low temperatures, it slowly decomposed at $\mathrm{T}>0{ }^{\circ} \mathrm{C}$, as indicated by a colour change from orange to green. Well formed green crystals were obtained by slow crystallization from $\mathrm{THF} /$ pentane at $-20^{\circ} \mathrm{C}$. The X-ray diffraction analysis revealed the identity of the compound as the $\mathrm{H}_{2}$ elimination product, $\left[\mathrm{Cp}^{t \mathrm{Bu}} \mathrm{Mo}\left(\mathrm{PMe}_{3}\right)_{2} \mathrm{H}\right]^{+} \mathrm{PF}_{6}{ }^{-}$, see Figure 3. ${ }^{[20]}$ Its formation from $\left[\mathrm{Cp}^{t \mathrm{Bu}} \mathrm{Mo}\left(\mathrm{PMe}_{3}\right)_{2} \mathrm{H}_{3}\right]^{+}$can be viewed as the collapse of the $\mathrm{H} 2$ and $\mathrm{H} 3$ atoms (Figure $1 \mathrm{~b}$ ) to yield a putative $\left[\mathrm{Cp}^{t \mathrm{Bu}} \mathrm{Mo}\left(\mathrm{PMe}_{3}\right)_{2}\right.$ $\left.\mathrm{H}\left(\mathrm{H}_{2}\right)\right]^{+} \mathrm{PF}_{6}-$ nonclassical intermediate, followed by $\mathrm{H}_{2}$ dissociation. Although, once again, structural parameters involving the hydride position may be imprecise, the quality of the data set allowed the identification of a single hydride ligand with a high level of confidence. Therefore, the product is a 15-electron complex of $\mathrm{Mo}^{\mathrm{III}}$. When protected from air, the compound is stable over several months in the solid state and at least for several hours in THF solution at room temperature. This stability can be attributed to steric protection, since no additional electron density is available on the ligands for a $\pi$-stabilization mechanism.

\section{<insert Figure 2 here>}

Figure 3. ORTEP view of the cation in $\left[\mathrm{Cp}^{\mathrm{tB} u} \mathrm{Mo}\left(\mathrm{PMe}_{3}\right)_{2} \mathrm{H}\right] \mathrm{PF}_{6}$. Ellipsoids are drawn at the $30 \%$ probability level. All hydrogen atoms except the hydride are not shown for clarity. Distances $(\AA)$ : Mo-CNT, 2.0096(3); Mo-P1, 2.4801(8); Mo-P2, 2.4685(9); Mo-H1, 1.83(3).40. Relevant angles $\left({ }^{\circ}\right)$ : CNT-Mo-P1, 122.02(2); CNT-Mo-P2, 121.57(2); P1-Mo-P2, 109.55(3); CNT-Mo-H1, 125.2(9). CNT is the $\mathrm{Cp}^{\mathrm{BBu}}$ ring centroid.

Although the 15-electron configuration is quite common in the coordination chemistry of $\mathrm{Mo}^{\mathrm{III}}$ (associated without fail to a spin quartet state), it is extremely rare for organometallic compounds for reasons related to the lower cost of electron pairing in the presence of softer organic ligands. ${ }^{[21,22]}$ Two examples, which also enjoy high steric protection and adopt a spin quartet ground state, are $\left[\left(\mathrm{C}_{5} \mathrm{Ph}\right)_{2} \mathrm{Mo}^{+[23]}\right.$ and $\mathrm{Mo}\left(\mathrm{SPhMes}_{2}\right)_{3} .^{[24]}$ Open-shell hydride complexes are also extremely rare. An example with a 15-electron configuration is $\left(\mathrm{Tp}^{\mathrm{tBu}, \mathrm{Me}}\right) \mathrm{CoH} .^{[25]}$

The spin configuration for complex $\left[\mathrm{Cp}^{t \mathrm{Bu}} \mathrm{Mo}\left(\mathrm{PMe}_{3}\right)_{2} \mathrm{H}\right]^{+}$could not be determined by magnetic methods, because of our inability to prepare a pure bulk sample (the compound crystallized together with other decomposition products, e.g. $\left[\mathrm{Cp}^{t \mathrm{Bu}} \mathrm{Mo}\left(\mathrm{PMe}_{3}\right)_{2} \mathrm{H}_{4}\right]^{+}$obtained by proton transfer processes ${ }^{[26]}$ ). However, we were able to confirm the spin quartet ground state by EPR spectroscopy. Unlike the spin doublet configuration, a spin quartet ground state is notoriously difficult to observe by EPR spectroscopy for $2^{\text {nd }}$ and $3^{\text {rd }}$ row transition metals with large zero-field splitting. According to theory, a slightly rhombically distorted tetragonal tensor should have $\mathrm{g}_{\mathrm{x}}$ and $\mathrm{g}_{\mathrm{y}}$ close to 4 and $\mathrm{g}_{\mathrm{z}}$ close to 2 for the spin-allowed $\pm 1 / 2$ transition. ${ }^{[27]}$ In addition, a spin forbidden $\pm 3 / 2$ transition may also be accessible, yielding a weak feature at $\mathrm{g}$ ca. 6 for the $\mathrm{z}$ component. A rare example for $\mathrm{Mo}^{\mathrm{III}}$ is given by $\mathrm{Mo}(\mathrm{acac})_{3}$, for which a relatively broad spectrum can be observed between the liquid $\mathrm{N}_{2}$ and the liquid He temperatures. ${ }^{[28]}$ Solutions of $\left[\mathrm{Cp}^{t \mathrm{Bu}} \mathrm{Mo}\left(\mathrm{PMe}_{3}\right)_{2} \mathrm{H}\right] \mathrm{PF}_{6}$ in THF were EPR silent at room temperature and showed only a small resonance at the liquid nitrogen temperature, characteristic of residual $\left[\mathrm{Cp}^{t \mathrm{Bu}} \mathrm{Mo}\left(\mathrm{PMe}_{3}\right)_{2} \mathrm{H}_{3}\right] \mathrm{PF}_{6}$. The solid sample, however, exhibited the features shown in Figure 4 at liquid He temperature. The $g$ tensor $\mathrm{x}$ and $\mathrm{y}$ components ( $\pm 1 / 2$ transition) are indeed visible at $g=3.74$ and ca. 3.45 , as well as a weak feature attributed to the $\pm 3 / 2$ transition ( $\mathrm{z}$ component) at $\mathrm{g}=5.33$. The $\mathrm{g}=3.74$ peak appears to display a fine structure, possibly due to coupling to the two equivalent $P$ nuclei. The $g_{z}$ component of the $\pm 1 / 2$ transition is not visible because it is overshadowed by stronger resonances of residual 17-electron trihydride at $\mathrm{g}=2.009$.

<insert Figure 4 here>

Figure 4. Liquid $\mathrm{He}$, X-band EPR spectrum of compound $\left[\mathrm{Cp}^{\mathrm{tBu}} \mathrm{Mo}\left(\mathrm{PMe}_{3}\right)_{2} \mathrm{H}\right] \mathrm{PF}_{6}$ (polycrystalline solid sample).

In summary, we have presented the first structural characterization of the starting and end products of an $\mathrm{H}_{2}$ oxidatively induced reductive elimination. The end product is a rare example of a 15-electron hydride complex.

\section{Experimental Section}

All operations were carried out under an argon atmosphere with Schlenk line and dry box techniques. Solvents were dehydrated by standard methods and distilled under dinitrogen. Instrumentation used was: cyclic voltammetry, EG\&G 362 potentiostat; ${ }^{1} \mathrm{H}$ and ${ }^{31} \mathrm{P}$ NMR, Bruker AC200; EPR, Bruker ESP300; X-ray diffraction, OxfordDiffraction XCALIBUR and Stoe IPDS. Compound $\mathrm{Cp}^{\mathrm{tBu}} \mathrm{MoCl}_{4}$ was obtained from $\mathrm{Cp}^{\mathrm{tBu} \mathrm{Mo}}(\mathrm{CO})_{3}\left(\mathrm{CH}_{3}\right)$ and $\mathrm{PhICl}_{2}$, the carbonyl compound being obtained in turn from $\mathrm{Mo}(\mathrm{CO})_{6}$ and $\mathrm{NaCp}^{\mathrm{tBu}}$, by adapting the literature procedure used for the $\mathrm{Cp}^{\star}$ analogue. ${ }^{[29]}$

Preparation of $\mathrm{Cp}^{\mathrm{ABu}} \mathrm{Mo}\left(\mathrm{PMe}_{3}\right)_{2} \mathrm{H}_{3}$ : To compound $\mathrm{Cp}^{\mathrm{ABu}} \mathrm{MoCl}_{4}(1.42 \mathrm{~g}$, $3.00 \mathrm{mmol})$ in THF $(20 \mathrm{~mL})$ was added $\mathrm{PMe}_{3}$ in THF $(1 \mathrm{M}, 8 \mathrm{~mL}, 8$ $\mathrm{mmol})$. After stirring for $30 \mathrm{~min}$, a suspension of $\mathrm{LiAlH}_{4}(\mathrm{ca} .650 \mathrm{mg})$ in THF $(40 \mathrm{~mL})$ was carefully added, resulting in gas evolution. After stirring for $5 \mathrm{~h}, \mathrm{MeOH}$ (ca. $6 \mathrm{~mL}$ ) was added dropwise causing vigorous gas evolution. After an additional $1 \mathrm{~h}$ stirring the suspension was vacuum-dried. The residue was then extracted with $\mathrm{Et}_{2} \mathrm{O}$ (ca. 150 $\mathrm{mL}$ ) and filtered through Celite. The final solution was vacuum-dried, and the pale yellow solid was washed with methanol and dried in vacuo. Yield: $727 \mathrm{mg}(50 \%)$. Anal. Calcd. for $\mathrm{C}_{23} \mathrm{H}_{50} \mathrm{MoP}_{2}$ : C, 57.01; $\mathrm{H}, 10.40$. Found: $\mathrm{C}, 56.48 ; \mathrm{H}, 10.88 .{ }^{1} \mathrm{H}$ NMR $\left(\mathrm{C}_{6} \mathrm{D}_{6}\right): \delta-5.20(\mathrm{t}, \mathrm{J}=$ $51.0 \mathrm{~Hz}, 3 \mathrm{H}, \mathrm{Mo}-\mathrm{H}), 1.37\left(\mathrm{~s}, 9 \mathrm{H},{ }^{\mathrm{t}} \mathrm{Bu}\right), 1.49\left(\mathrm{br}, 18 \mathrm{H}, \mathrm{P}\left(\mathrm{CH}_{3}\right)_{3}\right), 1.58$ $\left(\mathrm{s}, 18 \mathrm{H}, 2 \times{ }^{\mathrm{t}} \mathrm{Bu}\right), 4.86\left(\mathrm{~s}, 2 \mathrm{H}, \mathrm{C}_{5} \mathrm{H}_{2}{ }^{\mathrm{B}} \mathrm{Bu} \mathrm{u}_{3}\right) .{ }^{31} \mathrm{P}\left\{{ }^{1} \mathrm{H}\right\} \operatorname{NMR}\left(\mathrm{C}_{6} \mathrm{D}_{6}\right): \delta 17.9$ (s). A single crystal for the $\mathrm{X}$-ray analysis was obtained by slow diffusion of a $\mathrm{MeOH}$ layer into a pentane solution at $5^{\circ} \mathrm{C}$.

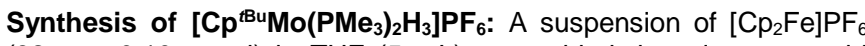
$(32 \mathrm{mg}, 0.10 \mathrm{mmol})$ in THF $(5 \mathrm{~mL})$ was added dropwise to a cold solution (193 K) of $\mathrm{Cp} p^{\mathrm{tBu}} \mathrm{Mo}\left(\mathrm{PMe}_{3}\right)_{2} \mathrm{H}_{3}$ (53 mg, $\left.0.11 \mathrm{mmol}\right)$ in tetrahydrofuran $(10 \mathrm{~mL})$. The solution color immediately changed from pale yellow to dark blue and, within a few minutes, to orange. The reaction mixture was slowly warmed up to $253 \mathrm{~K}$ and then concentrated to ca. $1 \mathrm{~mL}$. Addition of cold pentane (253 K, 10 $\mathrm{mL}$ ) afforded a brown precipitate that was decanted and further washed with cold pentane $(253 \mathrm{~K}, 3 \times 10 \mathrm{~mL})$ and finally vacuum-dried. Yield: $48 \mathrm{mg}, 70 \%$. A single crystal for the X-ray analysis was obtained by diffusion of a pentane layer onto a THF solution at $-80^{\circ} \mathrm{C}$. EPR (THF, $193 \mathrm{~K}$ ): $\mathrm{g}=2.016$ (triplet of quartets) $\mathrm{a}_{\mathrm{P}}=36.2 \mathrm{G}, \mathrm{a}_{\mathrm{H}}=$ $11.4 \mathrm{G}$ and $\mathrm{a}_{\mathrm{Mo}}=30.8 \mathrm{G}$.

Received: ((will be filled in by the editorial staff))

Published online on ((will be filled in by the editorial staff)) 
Keywords: Molybdenum · Hydride ligands · Paramagnetic organometallic complexes - Oxidatively induced reductive elimination EPR spectroscopy · X-ray crystallography

[1] O. B. Ryan, M. Tilset, V. D. Parker, J. Am. Chem. Soc. 1990, 112, 2618

[2] K.-T. Smith, C. Rømming, M. Tilset, J. Am. Chem. Soc. 1993, 115, 8681 .

[3] B. Pleune, D. Morales, R. Meunier-Prest, P. Richard, E. Collange, J. C. Fettinger, R. Poli, J. Am. Chem. Soc. 1999, 121, 2209.

[4] R. Poli, in Recent Advances in Hydride Chemistry (Eds.: R Poli, M. Peruzzini), Elsevier Science, Amsterdam, 2001, pp. 139.

[5] S. Foerster, M. Stein, M. Brecht, H. Ogata, Y. Higuchi, W. Lubitz, J. Am. Chem. Soc. 2003, 125, 83.

[6] R. Y. Igarashi, M. Laryukhin, P. C. Dos Santos, H.-I. Lee, D. R. Dean, L. C. Seefeldt, B. M. Hoffman, J. Am. Chem. Soc. 2005, 127, 6231.

[7] F. Gloaguen, J. D. Lawrence, T. B. Rauchfuss, J. Am. Chem. Soc. 2001, 123, 9476.

[8] R. Mejia-Rodriguez, D. S. Chong, J. H. Reibenspies, M. P. Soriaga, M. Y. Darensbourg, J. Am. Chem. Soc. 2004, 126, 12004.

[9] D. G. Morrell, J. K. Kochi, J. Am. Chem. Soc. 1975, 97, 7262 .

[10] T. T. Tsou, J. K. Kochi, J. Am. Chem. Soc. 1978, 100, 1634.

[11] W. Lau, J. C. Huffman, J. K. Kochi, Organometallics 1982, 1,155 .

[12] A. Pedersen, M. Tilset, Organometallics 1993, 12, 56.

[13] A. A. Zlota, M. Tilset, K. G. Caulton, Inorg. Chem. 1993, 32,3816 .

[14] A. Pedersen, M. Tilset, Organometallics 1994, 13, 4887.

[15] M. T. Costello, R. A. Walton, Inorg. Chem. 1988, 27, 2563.

[16] K.-T. Smith, M. Tilset, R. Kuhlman, K. G. Caulton, J. Am. Chem. Soc. 1995, 117, 9473.

[17] R. Poli, M. Baya, R. Meunier-Prest, S. Raveau, New J. Chem. 2006, 30, 759

[18] B. Pleune, R. Poli, J. C. Fettinger, Organometallics 1997, 16, 1581 .

[19] J. C. Fettinger, B. Pleune, R. Poli, J. Am. Chem. Soc. 1996, $118,4906$.

[20] The structures were solved by direct methods (SIR97) and refined by full matrix least-squares (SHELXL97). H atoms were treated with the riding model except for the hydrides which were fully refined with isotropic thermal parameters. Crystallographic data (excluding structure factors) have been deposited with the Cambridge Crystallographic Data Centre as supplementary publication no. CCDC 619352 - 619354. X-ray data. (a) $\mathbf{C p}^{t \mathbf{B u}} \mathbf{M o}\left(\mathbf{P M e}_{3}\right)_{2} \mathbf{H}_{3}: \mathrm{C}_{23} \mathrm{H}_{50} \mathrm{MoP}_{2}, \mathrm{M}_{\mathrm{r}}=484.51$ monoclinic, space group $\mathrm{P} 21 / \mathrm{n}, \mathrm{a}=16.2915(15), \mathrm{b}=$ 17.4655(16), $\mathrm{c}=9.2144(8) \AA, \beta=92.651(10)^{\circ}, \mathrm{V}=$ 2619.1(4) $\AA^{3}, Z=4, \rho$ calcd $=1.229 \mathrm{~g} / \mathrm{cm}^{-3}, \mu=0.629 \mathrm{~mm}^{-1}$, MoK $\alpha$ radiation $(\lambda=0.71073 \AA), \mathrm{T}=180 \mathrm{~K}, 2 \theta_{\max }=$ 52.32 , scan mode $=\varphi$ (Stoe IPDS diffractometer $), 20750$ measured (5171 independent, $\left.\mathrm{R}_{\text {int }}=0.0337\right)$ reflection, 262 refined parameters. Absorption correction (Multiscan), transmission factors $0.8299 / 0.7768 . \mathrm{R}=0.0270$, wR $=0.0657$ refined against $\left|\mathrm{F}^{2}\right|, \mathrm{GOF}=1.034,[\Delta \rho]_{\max } 0.514$, $[\Delta \rho]_{\min }-0.524$ e. $A^{-3}$. (b) $\left[\mathbf{C p}^{t \mathbf{B u}} \mathbf{M o}\left(\mathbf{P M e}_{3}\right)_{2} \mathbf{H}_{3}\right] \mathbf{P F}_{6}$ : $\mathrm{C}_{23} \mathrm{H}_{50} \mathrm{~F}_{6} \mathrm{MoP}_{3}, \mathrm{M}_{\mathrm{r}}=629.48$, monoclinic, space group $\mathrm{P} 2{ }_{1} / \mathrm{c}, \mathrm{a}=14.0847(10), \mathrm{b}=26.216(2), \mathrm{c}=20.1855(15) \AA$, $\beta=99.221(8)^{\circ}, \mathrm{V}=7357.2(10) \AA^{3}, \mathrm{Z}=8$, $\rho_{\text {calcd }}=1.269$ $\mathrm{g} / \mathrm{cm}^{-3}, \mu=0.535 \mathrm{~mm}^{-1}, \operatorname{MoK} \alpha$ radiation $(\lambda=0.71073 \AA)$, $\mathrm{T}=180 \mathrm{~K}, 2 \theta_{\max }=50.00$, scan mode $=\varphi($ Stoe IPDS diffractometer), 50093 measured (12934 independent, $\mathrm{R}_{\text {int }}$ $=0.0853$ ) reflection, 763 refined parameters. Absorption correction (Multi-scan), transmission factors $0.8843 / 0.8674 . \mathrm{R}=0.0488, \mathrm{w} \mathrm{R}=0.1052$ refined against $\left|\mathrm{F}^{2}\right|, \mathrm{GOF}=0.835,[\Delta \rho]_{\max } 0.802,[\Delta \rho]_{\min }-0.441 \mathrm{e} . \mathrm{A}^{-3}$. (c) [C $\left.{ }^{t \text { Bu }} \mathbf{M o}\left(\mathbf{P M e}_{3}\right)_{2} \mathbf{H}\right] \mathbf{P F}_{6}: \mathrm{C}_{23} \mathrm{H}_{48} \mathrm{~F}_{6} \mathrm{MoP}_{3}, \mathrm{M}_{\mathrm{r}}=627.46$, monoclinic, space group $\mathrm{P} 2{ }_{1} / \mathrm{c}, \mathrm{a}=9.6185(5), \mathrm{b}=$ 16.8699(10), $\mathrm{c}=18.7489(12) \AA, \beta=90.441(5)^{\circ}, \mathrm{V}=$ 3042.2(3) $\AA^{3}, Z=4$, $\rho_{\text {calcd }}=1.370 \mathrm{~g} / \mathrm{cm}^{-3}, \mu=0.636 \mathrm{~mm}^{-1}$, MoK $\alpha$ radiation $(\lambda=0.71073 \AA), T=180 \mathrm{~K}, 2 \theta_{\max }=$ 52.74 , scan mode $=\omega$ and $\varphi$ (Oxford-Diffraction XCALIBUR diffractometer), 25511 measured (18993 independent, $R_{\text {int }}=0.0513$ ) reflection, 317 refined parameters. Absorption correction (Multi-scan), transmission factors $0.8363 / 0.7206 . \mathrm{R}=0.0507, \mathrm{wR}=$ 0.1428 refined against $\left|\mathrm{F}^{2}\right|, \mathrm{GOF}=1.070,[\Delta \rho]_{\max } 1.073$, $[\Delta \rho]_{\min }-0.981$ e. $\mathrm{A}^{-3}$.

R. Poli, Chem. Rev. 1996, 96, 2135.

[22] R. Poli, J. Organomet. Chem 2004, 689, 4291-4304.

[23] W. Hübel, R. Merényi, J. Organometal. Chem. 1964, 2, 213

[24] B. S. Buyuktas, M. M. Olmstead, P. P. Power, Chem. Commun. 1998, 1689.

[25] J. D. Jewson, L. M. Liable-Sands, G. P. A. Yap, A. L. Rheingold, K. H. Theopold, Organometallics 1999, 18, 300

[26] This compound has been isolated and fully characterized, including by X-ray crystallography. Details will be presented in a forthcoming full paper.

[27] E. Muenck, H. Rhodes, W. H. Orme-Johnson, L. C. Davis, W. J. Brill, V. K. Shah, Biochimica et Biophysica Acta, Protein Structure 1975, 400, 32.

[28] B. A. Averill, W. H. Orme-Johnson, Inorg. Chem. 1980, 19, 1702.

[29] D. W. Keogh, R. Poli, in Synthetic Methods of Organometallic and Inorganic Chemistry (Herrmann/Brauer), Vol. 8 (Ed.: W. A. Herrmann), Georg Thieme Verlag, Stuttgart, 1997, p. 98. 

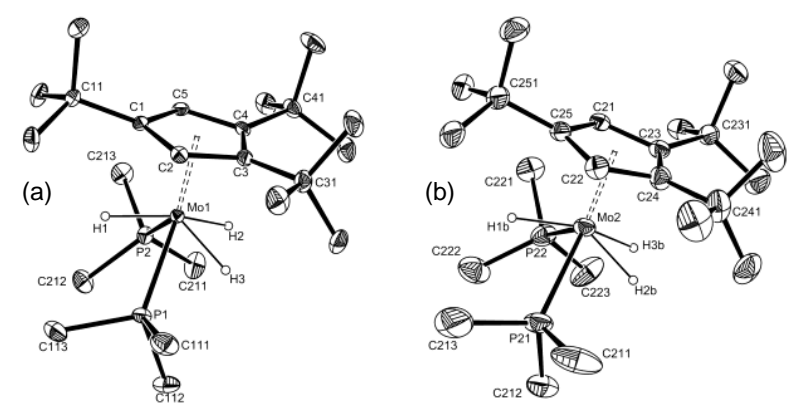

Figure 1

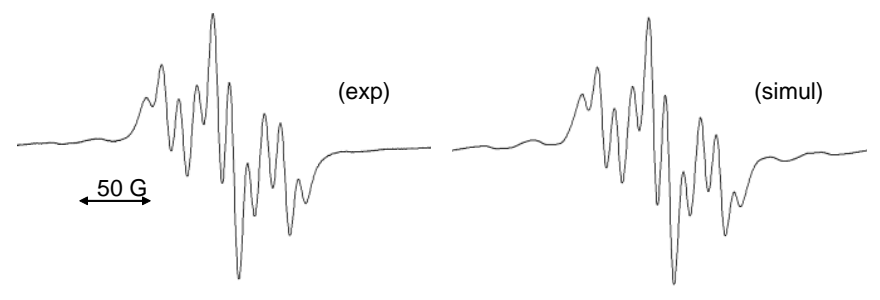

Figure 2

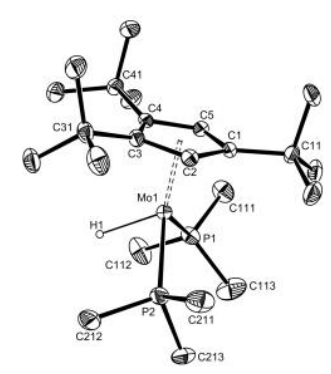

Figure 3

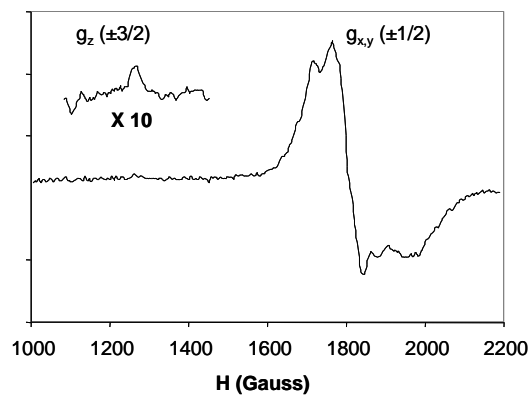

Figure 4 
Sterically protected 15-electron

molybdenum hydride

Miguel Baya, Jennifer Houghton, Jean-

Claude Daran, Rinaldo Poli*

Formation and structure of a sterically protected molybdenum hydride

complex with a 15-electron

configuration: [(1,2,4-

$\left.\mathrm{C}_{5} \mathrm{H}_{2} \mathrm{Bu}_{3}\right) \mathrm{Mo}\left(\mathrm{PMe}_{3}\right)_{2} \mathrm{H}^{+}$
Oxidation of $(1,2,4-$

$\left.\mathrm{C}_{5} \mathrm{H}_{2} t \mathrm{Bu}_{3}\right) \mathrm{Mo}\left(\mathrm{PMe}_{3}\right)_{2} \mathrm{H}_{3}$ induces $\mathrm{H}_{2}$ reductive elimination and yields the first stable 15-electron hydride complex, [(1,2,4-

$\left.\left.\mathrm{C}_{5} \mathrm{H}_{2} t \mathrm{Bu}_{3}\right) \mathrm{Mo}\left(\mathrm{PMe}_{3}\right)_{2} \mathrm{H}\right]^{+}$.

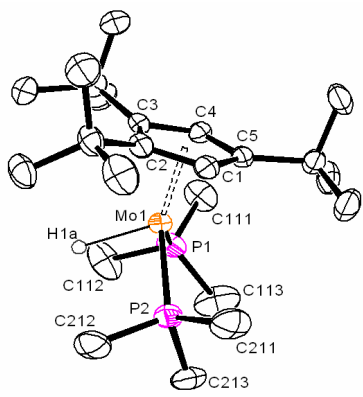


